\title{
Processing of Banana Flour Using a Local Banana as Raw Materials in Lampung
}

\author{
Alvi Yani, Ratna Wylis Arief, Nina Mulyanti \\ Lampung Assessment Institute for Agricultural Technology \\ Jl Z.A. Pagar Alam No, 1 A. Raja Basa. Bandar Lampung \\ Email : alvi_yani64@yahoo.com
}

\begin{abstract}
The research aims to get the best local banana from several aspects (rendement total sugar content, organoleptic and nutritional value) in the process into banana flour (BF). Research conducted in July-September 2010 and mature green bananas were collected from the farmer's field of Pardasuka Village, Ketibung District, South Lampung Regency. Research conducted using randomized design with four banana types, a). Janten, b). Kepok Manado, c). Muli and d), Raja Nangka.. Analyses carried out on rendement, nutritional value, total sugar and whiteness. Organoleptic test was done for knowing customer preferences (color, flavor and texture) by 20 panelists with score 1 to 7 (very not like s/d really like). Results showed that rendement of BF from Janten was the highest (range of recovery 35-36\%) followed by BF from Raja Nangka (20-21\%), Kepok Manado (20\%) and Muli (16-17\%). The highest total sugar was BF from Muli i.e .7.784\% followed by Raja Nangka (4.985\%), Kepok Manado (4.961\%) and Janten (3.732\%), whereas whiteness ranges from 42.85 to $61,55 \%$ with the highest levels of whiteness of BF from Kepok Manado (61.55\%), followed Janten (54\%), Raja Nangka (43.25\%) and the lowest of Muli (42.85\%). The BF contained protein (from 2.545 to $3.407 \%$ ), fat (from 0.433 to $0.583 \%$ ), carbohydrate (from 83.400 to 88.005\%), ash (from 2.053 to $3.031 \%$ ), crude fiber (from 0.524 to 1.897 ) and moisture content (from 5.586 to 6.603\%). The BF from Raja Nangka showed good characters $($ color $=5.92)$, $($ texture $=5.69)$, and $($ flavor $=5.31)$ and panelist acceptance. Based on consideration of several aspects such as rendement, total sugar, consumer preferences, availability of raw materials and business analyses, the best bananas to be processed into flour in Lampung was the Raja Nangka banana and be able to increase the added value of $>15 \%$ with $\mathrm{B} / \mathrm{C}$ ratio of 1.32 and competent to be developed.
\end{abstract}

Keyword-- Banana Flour (Bf); Janten; Kepok Manado Muli; Raja Nangka.

\section{INTRODUCTION}

Banana (Musa paradisiaca) is one of the commodities that have a very high chance for diversification, food security and agribusiness in Indonesia. This is not only because of the potential of carbohydrates, nutrients, minerals and fiber content are highly qualified as food commodities and food diet, but also because the optimal total production per ha which ranged from 25 to 40 ton $^{[1]}$. Lampung Provincial Government is very supportive banana as the main commodity with the potential of generating plant 9,155,382 trees, and a production of 549928 tons. Largest production center is the South Lampung regency with potential generating plant 5,654,854 trees and a production of 391523 tons $^{[2]}$.

Banana is a tropical fruit that easily rot, fruit color has changed rapidly by physical influences such as sunlight and cuts, and influence of biological (fungus). On the other hand, the current banana production is relatively abundant, especially in Lampung with an unbalanced market uptake. Therefore, post-harvest handling of banana cultivation is essential to prolong the shelf, so it can be a value-added product. In addition, the diversification of food is a way out which is currently considered the most rational way to solve the problem of meeting the needs of food especially carbohydrates. Through compliance with a diet that does not originate from a single food source, allowing people to define their own food choices, food security raise their families, which leads to an increase in national food security. Bananas can be processed and preserved to various forms of processed products such as banana flour, banana sale, banana juice, banana wine, dodol banana, banana chips, banana sauce and banana jam and other processed ${ }^{[3] \text {. }}$

In an effort to develop a banana as a manifestation of people's food menu diversification, processing bananas into banana flour are the main alternatives that have good prospects, because the processing technology is quite simple, not easy damaged, can be stored for longer, giving higher value-added, more easily in packaging and transport, more practical for processed product diversification, to create business opportunities and the development of rural agroindustries can be processed into various types of food ${ }^{[4]}$. Banana flour (BF) is a product between the prospective in 
the development of local food source. Bananas quite suitable for processing into flour as the main constituent components are carbohydrates (17.2 to $38 \%)^{[5]}$.

Lampung province is known as one of the banana production centers in Indonesia with the various types of bananas that were found in this area such as Kepok, King Fur, King Jackfruit, Muli and Janten. The objective was to obtain the best kind of local bananas in the process into BF. Event handling bananas into BF can support the program areas of Lampung Province and the National Program for Development of Horticulture Area, because it can develop industrial and commodity-based small businesses bananas ${ }^{[6]}$.

\section{MATERIALS AND METHODS}

\section{A. Time and Place}

Research conducted at the Lampung Assessment Institute for Agricultural Technology Laboratory and the Laboratory of agricultural technology laboratory, Polinela Lampung in July-September 2010. Banana as raw materials acquired from farmers in the Pardasuka Village, Ketibung District, South Lampung regency is one banana production centers in Lampung province. Four (4) types of bananas were used, namely: Janten, Kepok Manado, Muli and Raja Nangka with the maturity level of $70-80 \%$.

\section{B. Materials and Equipment}

Supporting materials in addition to raw materials (4 varieties of bananas) was sodium meta bisulphite, the necessary tools were a knife, cutting board, bucket, container dryers, hummer mill and sieve the flour and plastic packaging/jar.

\section{Research methods and Parameters Test}

BF processing research conducted using Randomized Block Design (RBD) with 4 treatment varieties of bananas are dominant in Lampung (Janten, Kepok Manado, Muli and Raja Nangka). The data were statistically analyzed and followed by Duncan test at 5\% level and presented in graphs and tables.

$\mathrm{BF}$ processing carried out in two stages, namely making of banana chips and flour. The first stage, each $2 \mathrm{~kg}$ of bananas steamed for 10 minutes and then peeled and thinly sliced pieces of banana slices soaked in $0.3 \%$ sodium metabisulphite for 5 minutes, then drained. Banana slices dried in an oven at a temperature of $60^{\circ} \mathrm{C}$ for 24 hours. The result was called a dried banana chips. Dried banana chips milled and produce banana flour (BF) a pass 80 mesh sieve (Figure 1). BF was packed in a plastic bag and then rated $[3,6,7,8,9]$.

The parameters measured were the physico-chemical characteristics of banana starch, such as flour yield, moisture content, ash, crude fiber, carbohydrates, fats, proteins, whiteness and total sugar content. Analysis of moisture, ash and crude fiber was conducted by Graphymeter ${ }^{[10]}$, carbohydrate levels performed by the method by difference, protein content using Gunning method ${ }^{10}$, fat content by using Extraction method ${ }^{[10]}$, total sugars using the method of Luff Shoorl $^{[10]}$ and whiteness measurement with Whiteness meter. Organoleptic tests carried out to determine consumer preferences toward the four banana flour, and panelists about
20 people. The criteria tested were flavor, color, and texture by using a score of 1 to 7 ( $1=$ strongly dislike, $2=$ dislike, 3 $=$ rather dislike, $4=$ neutral, $5=$ rather like, $6=$ like, and $7=$ very like).

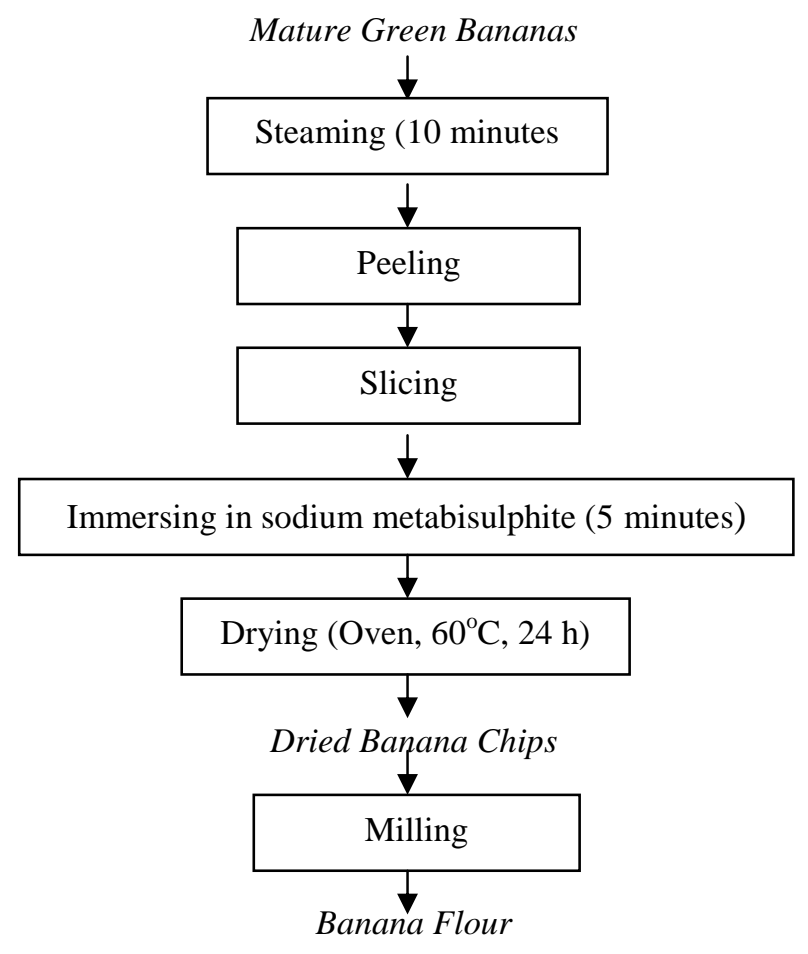

Figure 1. Flow chart of banana flour processing

\section{RESULTS AND DISCUSSION}

\section{A. Rendement Of $B F$}

Rendement of BF produced from the four treatment types of bananas were presented in Table 1. Table 1 showed that the rendement of BF produced ranges between 16-36\%,

The results showed that Janten banana has the highest recovery compared with other types of bananas, but the BF was less strong (Table 3.) and low sugar content (Figure 2), so that Janten BF could not be considered as a substitute for sugar in processed foods. While the Raja Nangka banana, despite having a lower rendement of Janten banana, but has a strong BF (Table 3) and total sugar content was quite high (Figure 2), so that Raja Nangka BF could be considered as a substitute for sugar in processed foods based flour.

TABLE.I.

RENDEMENT OF BF

\begin{tabular}{clc} 
No. & \multicolumn{1}{c}{ Banana Types } & Rendement of BF $(\%)$ \\
\hline 1. & Janten & $35-36$ \\
2. & Kepok Manado & $19-20$ \\
3. & Muli & $16-17$ \\
4. & Raja Nangka & $20-21$ \\
\hline
\end{tabular}

Recovery of BF was influenced by maturity level of a green bananas. The ideal criteria bananas used as the raw material of $\mathrm{BF}$ is mature green bananas, because in these conditions the starch content of the fruit reaches its maximum so suitable for the manufacture of flour ${ }^{[11]}$ 


\section{B. Nutrient Contents}

Nutrient analysis results of BF were presented in Table 2. Quality requirements $\mathrm{BF}$ has a maximum water content of $12 \%$. Moisture content of BF produced by the four types of banana flour had qualified quality SII 0426-81. Water content in a product affects the shelf life of the product ${ }^{[12]}$. Water levels are safe for flour that is $<12 \%$ so as to prevent the growth of fungi ${ }^{[13]}$.

TABLE.II

NUTRIENT CONTENTS OF BANANAS FLOUR

\begin{tabular}{|c|c|c|c|c|c|c|c|}
\hline $\begin{array}{r}\mathrm{N} \\
\mathrm{O}\end{array}$ & $\mathrm{BF}$ & $\begin{array}{c}\text { Moisture } \\
\text { content } \\
(\%)\end{array}$ & $\begin{array}{l}\text { Prot } \\
\text { ein } \\
(\%)\end{array}$ & $\begin{array}{l}\text { Fat } \\
(\%)\end{array}$ & $\begin{array}{l}\text { Carbo } \\
\text { hydrat } \\
\text { e }(\%)\end{array}$ & $\begin{array}{l}\text { Ash } \\
(\%)\end{array}$ & $\begin{array}{l}\text { Crude } \\
\text { fiber } \\
(\%)\end{array}$ \\
\hline 1. & Janten & 6,39 & 5,58 & 0,49 & 83,40 & 2,24 & 1,90 \\
\hline 2. & $\begin{array}{l}\text { Kepok } \\
\text { Manado }\end{array}$ & 5,73 & 2,80 & 0,58 & 88,00 & 2,05 & 0,83 \\
\hline 3. & Muli & 6,60 & 2,55 & 0,43 & 86,56 & 3,03 & 0,83 \\
\hline 4. & $\begin{array}{l}\text { Raja } \\
\text { Nangka }\end{array}$ & 5,59 & 3,41 & 0,47 & 87,77 & 2,39 & 0,52 \\
\hline
\end{tabular}

BF contain complete nutrient. Table 2. showed that the main nutritional components of $\mathrm{BF}$ was a carbohydrate. Range of $\mathrm{BF}$ carbohydrates produced between 83.40 to $88.00 \%$, the highest value was produced in BF from Kepok Manado, followed by BF from Raja Nangka, Muli and Janten .

The highest starch content present in fruits are green and unripe, like bananas and mangoes, reaching $70 \%$ of the dry weight. Therefore, bananas can be used as an alternative source other than corn starch, wheat, and rice ${ }^{14}$. Types of plantain bananas, very suitable for making flour because it has a fairly high solids content. Required in the manufacture of BF with a relatively high starch content, which is about 16.5 to $19.5 \%$. Bananas suitable for processing into flour, because the main constituent components are carbohydrates. Carbohydrates in a banana is a complex carbohydrate, which provides energy to the body that can be absorbed in the not prolonged, such as rice, bread, and biscuits, but also not too early as sugar or syrup ${ }^{[15]}$.

Protein content of $\mathrm{BF}$ obtained ranged from 2.55 to $3.41 \%$, the highest in BF from Janten, and the lowest in the $\mathrm{BF}$ from Muli. Differences in the protein content in the BF caused by different types of bananas were used, planting areas, weather and drying conditions.

Banana flour can be used as a diet food, because of the low fat content, while the fiber contained in the BF can help the process of digestion in the intestine. Fat of BF obtained (Table 2) ranged from 0.43 to $0.58 \%$, the highest in $\mathrm{BF}$ from Kepok Manado (0.58\%) and lowest in BF from Muli $(0.43 \%)$, this means that the level of fat contained in bananas was quite low. Bananas have a fairly low fat content, so it's good to be consumed as food die ${ }^{[16]}$.

Besides that BF has produced a fairly high ash content, ranging from 2.24 to $3.03 \%$ and the crude fiber content ranges from 0.52 to $1.90 \%$ (Table 2), it means BF was also rich in minerals and fiber. Bananas are rich in minerals such as potassium, magnesium, phosphorus, iron, and calcium, in addition to bananas also contain vitamins, namely $\mathrm{C}, \mathrm{B}$ complex, B6, and serotonin is active as a neurotransmitter in the smooth functioning of the brain ${ }^{[17]}$.

\section{Total Sugar}

Analysis of total sugar of BF from four types of bananas, was presented in Figure 2.

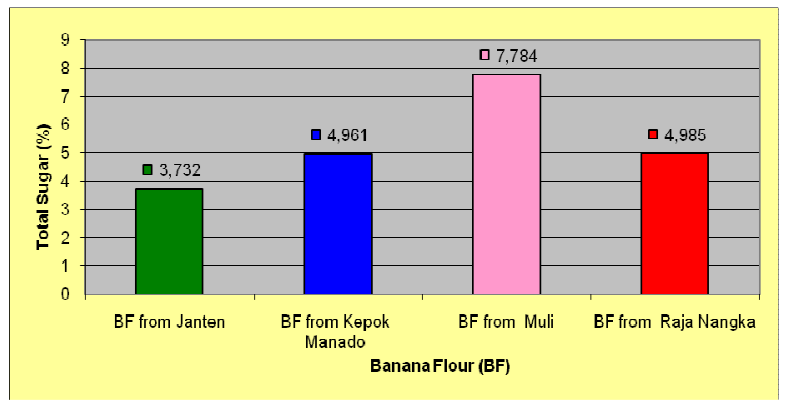

Fig. 2. Sugar content of banana flours (BF)

Figure 2 showed that the total sugar of $\mathrm{BF}$ ranged from 3.732 to $7.794 \%$ with the highest total sugar was BF from Muli $(0.794 \%)$, followed by BF from Raja Nangka (4,985\%), Kepok Manado (4.961\%) and the lowest was BF from Janten $(3.732 \%)$. Total sugar content of BF is determined by the type, level of maturity and processing methods. Muli banana known as Lampung banana is a banana that can be consumed directly that has a sweet taste when mature, while the other three types of bananas are bananas processed.

Sugar content in the bananas are fruit sugar or fructose has a low glycemic index, and fruit sugar is good for consumption being able to provide for the body's energy reserves and energy for brain activity ${ }^{[18]}$. An increase in the total sugar in fruits is caused by changes in carbohydrate / starch into sugar in the fruit ${ }^{[19]}$.

\section{Whiteness}

Bananas are susceptible to browning commodity after the peel. This was due oxidation with air to form a browning reaction with the enzymes contained in the food. (browning enzymatic). Because the enzyme is browning reaction between oxygen and the phenolic compounds catalyzed by polyphenol oxidase. To avoid the formation of brown color in foodstuffs will be made of flour, can be done by preventing contact between the material and the air that has been peeled by soaking in water, the addition of salt solution, sodium metabisulphyte and inactivate enzymes in the process blansir ${ }^{[20]}$. Analysis of whiteness, determine the level of whiteness of bananas produced. Whiteness is an important parameter in the physical quality of banana flour as it pertains to consumer preferences ${ }^{[21]}$.

Analysis of BF whiteness of four types of bananas treatment were presented in Figure 3. Figure 3 showed that the levels of $\mathrm{BF}$ whiteness ranged from 42.85 to $61.55 \%$ with the highest whiteness levels of BF from Kepok Manado $(61.55 \%)$ and the lowest of BF from Muli $(42.85 \%)$. BF whiteness is largely determined by the type and level of maturity of the bananas. 


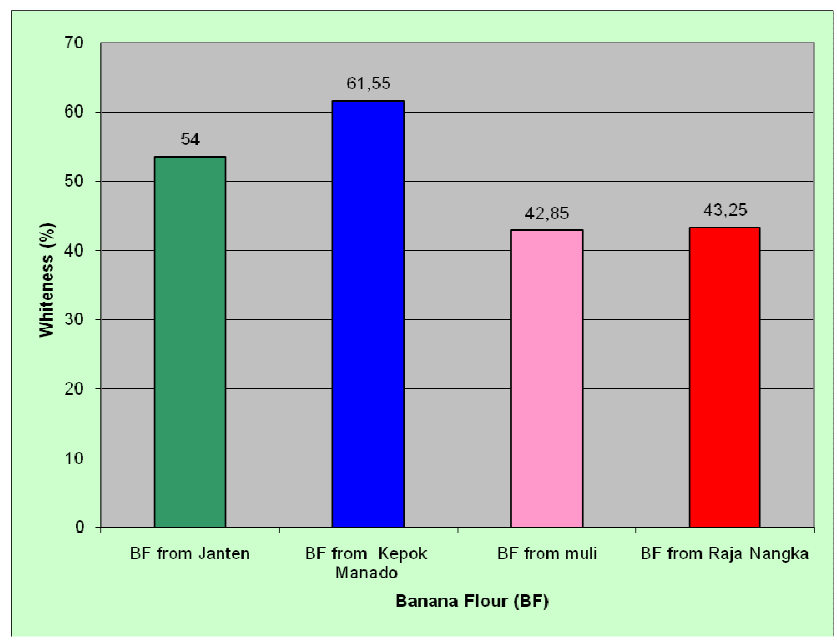

Figure 3. Whiteness of banana flours (BF)

Basically all kinds of raw bananas can be processed into flour, but the flour produced varied colors, because it is influenced by the rate of maturity, types and processing methods. Value of total sugar levels are usually negatively correlated with the value of the whiteness degree of BF. The higher the value of the total sugar in the lower value of the degree of whiteness. However, the results of research (Figures 2 and 3), showed that BF from Kepok Manado, despite having high levels of total sugar but had a high degree of whiteness values as well. Allegedly this was due by a genetic properties from Kepok Manado bananas fruit pulp that has a pure white color, while others have a type of banana flesh colored yellowish white.

The color of browning yellow BF is due Mailard reaction caused by caramelization process that occurs during drying, causing a browning yellow BF. Maillard reaction is the result of browning reaction between reducing sugars with amino acid groups ${ }^{[22]}$.

\section{E. Organoleptic Test}

Organoleptic test results for BF were presented in Table 3.

TABLE.III

ORGANOLEPTIC TEST FOR BANANA FLOUR (BF)

\begin{tabular}{|c|c|c|c|c|}
\hline \multirow{2}{*}{ No } & \multirow[t]{2}{*}{$\mathrm{BF}$} & \multicolumn{3}{|c|}{ Parameter } \\
\hline & & Color & Texture & Flavor \\
\hline 1. & BF from Janten & $4,92(a b)$ & 5,38 (a) & $4,15(b)$ \\
\hline 2. & $\begin{array}{l}\text { BF from Kepok } \\
\text { Manado }\end{array}$ & $5,23(a b)$ & 4,92(ab) & 4,38 (b) \\
\hline 3. & BF from $M u l i$ & 4,31 (b) & 4,23 (b) & 4,69 (ab) \\
\hline 4. & $\begin{array}{l}\text { BF from Raja } \\
\text { Nangka }\end{array}$ & 5,92 (a) & 5,69 (a) & $5,31(a)$ \\
\hline
\end{tabular}

Statistical analysis of the organoleptic test of some kind of BF (Table 3) showed that the BF from Raja Nangka has a color, texture, and flavor of the most preferred compared with other types of bananas. It was also known that BF from Raja Nangka has a high content of total sugar (4.985\%), while the BF from Muli, despite having the highest levels of total sugars $(7.784 \%)$, but has the color and texture were less preferred by consumers. This became the basis for selecting the Raja Nangka, as raw material for flour to be processed into a variety of processed foods in order to reduce the use of sugar (sugar substitute).

\section{F. Economic Analysis}

Based on the results of the previous test (organoleptic test, rendement and total sugar content), then the economic analysis performed for the BF from Raja Nangka. Results of economic analysis BF from Raja Nangka were presented in Table 4.

Results of economic analysis for the processing of BF from Raja Nangka (Table 4), indicated that the processing of $\mathrm{BF}$ gave a net profit of $\mathrm{Rp} .9 .700,-/$ bunch $(\mathrm{B} / \mathrm{C}$ ratio $=$ 1.32 ), thus it is feasible to develop.

\section{TABLE.IV.}

ECONOMIC ANALYSES OF BF FROM RAJA NANGKA FOR EVERY BUNCH (8 HAND)

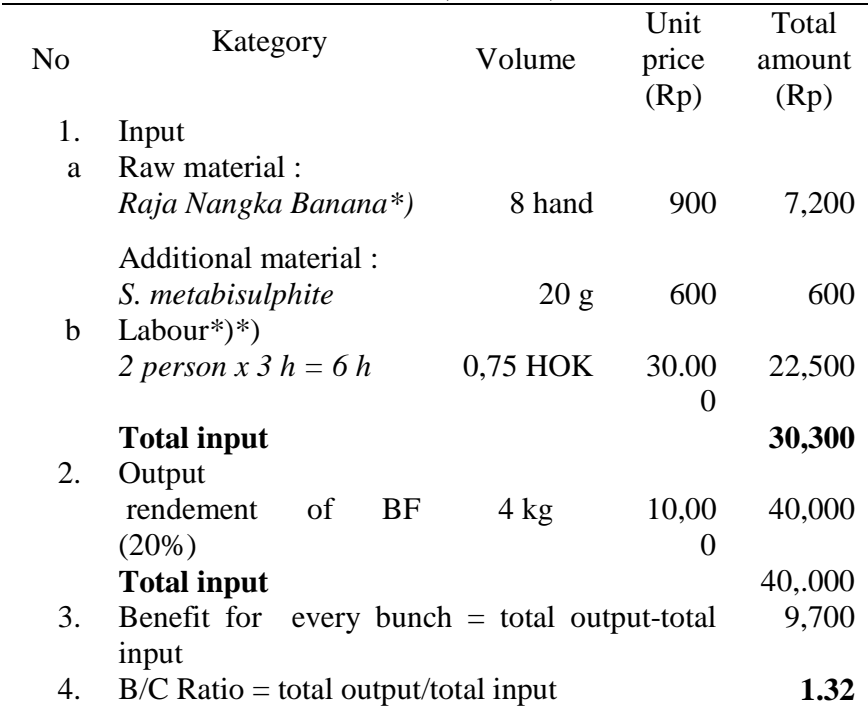

Remarks ;

*). Every bunch of Raja Nangka banana, have 8 figers and $\pi$ of weight $20 \mathrm{~kg}$

*). 1 HOK labour $=8$ h: labourage $=$ Rp. 30,0000,-/HOK.

\section{CONCLUSIONS}

Some conclusions from the results of this research were :

1. BF from Janten had the highest yield, with the range of $35-36 \%$, followed by BF from Raja Nangka (20-21\%), BF from Kepok Manado (20\%) and BF from Muli (16-17\%).

2. BF from Muli had the highest total sugar $7.784 \%$, followed by BF from Raja Nangka (4,985\%), BF from Kepok Manado (4.961\%) and BF from Janten $(3.732 \%)$.

3. Organoleptically, BF types were preferred by consumers was flour made from Raja Nangka banana (flavor, color and texture).

4. Based on consideration of several aspects such as yield, total sugar, consumer preferences, availability of raw materials and business analysis, then the best bananas to be processed into flour in Lampung was Raja Nangka . 
5. Processing of Raja Nangka banana into BF could increase the added value $>15 \%$ with the $B / C$ ratio of 1.32 , and the business is feasible to be developed.

\section{ACKNOWLEDGMENT}

This research was part of research funded by the Incentive Program Capacity Building Researchers and Engineers the 2010 budget year (PIPKPP 2010). Authors express gratitude and appreciation to the National Research Council, Ministry of Research and Technology for financial support through the program.

\section{REFERENCES}

[1] Directorate General of Horticulture Production. , 2003. Horticulture Yearbook 2003. $155 \mathrm{p}$.

[2] Statistics Lampung Province. 2010. Lampung in Figures 2009. C.V. Mulya. Bandar Lampung[3]. BPPHP. , 2004. Banana flour. Bulletin Teknopro Hortikulutra. Issue 72 (August 2004). Jakarta.

[3] Masli, R. 2007. Study for Making Banana Flour from Kepok (Musa paradisiaca Forma Typical) as Substituted Material Fresh Baking (Assesment of Banana Maturity Level from Kepok and Temperature Drying). Muhammadiyah University of Malang. http://studentresearch.umm.ac.id/research /download/umm_student_research _abstract_1747.pdf [18 Juli 2010].

[4] Kurniawan. , 2009. Flour Producing from Bananas. Sinar Tani, 18February 2009.

[5] Pratiwi, D.A.2008. Value Added Commodities of Banana and Influential Factors Against Income of Agroindustry of Sale Banana. http://digilib.unej.ac.id/go.php?id=gdlhub-gdl-grey-2008-dyahariest1451\&qterhadap\&PHPSESSID0ca14f93792a28e22ae4dcd1ab12c5b 4 [21 Jan 09].

[6] CTA.2000. Making Banana Chips and Flour. CTA Practical Guide Series, No. 11 The ACP-EU Technical Centre for Agricultural and Rural Cooperation (CTA). Wageningen, The Netherlands

[7] Daramola,B and Osanyinlusi, S.A. 2006. Production, Characterization and Application of Banana (Musa spp) Flour in Whole Maize. African Journal Biotechnology. Vol.5 (10) : 992-995.

[8] Suyanti and Supriyadi, A. , 2008. Bananas; Cultivation, Processingand Prospects. Penebar Swadaya. Jakarta.

[9] Research and Technology., 2009. Appropriate Technology (Banana Flour). http://www.iptek.net.id /ind/ warintek/?mnu=6\&ttg= $6 \& d o c=6 d 38$ [21 Oktober 2009].
[10] AOAC. 2005. Official of Analysis of The Association of Official Analytical Chemistry. Arlington. AOAC Inc.

[11] Antarlina, S.S., Y. Rina, S. Umar and Rukayah., 2004. Processing Bananas In Support of Agro-Industry Development in Kalimantan. In Proceedings of the National Seminar on Agricultural Technology Clinic For Base Growth Towards Farmers Agribusiness Independent Fishermen. Agricultural Socio-Economic Research and Development Center. Thing: 724-746.

[12] Buckle, KA, Edward, RA, Fleet, GH, M. Wootton Translated by Purnomo, H., Adiono. , 1987. Food Science. UI Press. Jakarta

[13] Winarno, F.G and S.L. Jenie. 1974. Basic Preservation, Sanitation and Poisoning. Department of Technology and Agriculture, Fatemeta, IPB. Bogor

[14] Perez, B., L. A., Agama-Acevedo, E., Sánchez-Hernández, L., \& Paredes-Lo'pez, O. (1999). Isolation and Partial Characterization of Banana Starches. Journal of Agricultural and Food Chemistry 47. $\mathrm{Hal}:$ 854-857.

[15] Widjaya, E.R. , 2009. Flour Processing Equipment and Machinery.. http://elita75.wordpress .com/2009/02/09/ unit-pengolahan-tepungpisang/ [ 21 Oktober 2009]

[16] Mohapatra. D., S. Mishra, C.B. Singh dan D.S.Jayas. 2010. Postharvest Processing of Banana : Opportunities and Challenges. Review Paper. Food Bioprocess Technol.http://resources .metapress.com/ pdf-preview.axd?code=b666477 74 29q8. [ 1 Maret 2011].

[17] Kumalasari, R. and Rohmah. L. , 2008. Characteristics of ripe banana flour (ripe banana powder) jackfruit varieties (Musa paradisiaca sp) after immersion in acid solution. Proceedings of the National Seminar on Science and Technology II. It 139-147.

[18] Sutomo, B. 2010. Bananas instant energy source and embarked brain function. http://myhobbyblogs.com/food/2008/12/04/pisangsumber-energi-instan-lancarkan-fungsi-otak/; [11 November 2010].

[19] Islam, M.S., M..Saiful Islam and A.H.M. F. Kabir. 2001. Effect of Postharvest Treatments with Some Coating material on The Shelf Life and Quality of Banana. Pakistan Journal of Biological Sciences. Vol. 4 (9) : 1149-1152.

[20] Widowati, S. , 2009. Flour Assorted Bulbs, A Food Security Solution. Sinar Tani 6 to 12 May 2009. No.3302, th XXXIX.

[21] Muchtadi, D And I.G. Samantha. , 1992. Formulation and Evaluation of the Quality of Food Hygiene Toddler Basic Materials Cassava Flour and Banana. Thesis. Graduate School, IPB. Bogor.

[22] Ardiansyah, D., 2005. Effect of Maillard reaction products (mrp) glucose - glycine on the growth of Salmonella typhimurium. Thesis. Department of Chemistry, Faculty Diponegoro University. Unpublished. 